\title{
"Fear" Is a Book of Fiction Mixed with Real Events
}

\author{
Freddy A. Paniagua \\ University of Texas Medical Branch, Galveston, USA \\ Email: faguapan@aol.com
}

How to cite this paper: Paniagua, F. A. (2019). "Fear" Is a Book of Fiction Mixed with Real Events. Open Journal of Political Science, 9, 107-121.

https://doi.org/10.4236/ojps.2019.91006

Received: November 30, 2018

Accepted: December 26, 2018

Published: December 29, 2018

Copyright $\odot 2019$ by author and Scientific Research Publishing Inc. This work is licensed under the Creative Commons Attribution International License (CC BY 4.0).

http://creativecommons.org/licenses/by/4.0/

\section{c) (i) Open Access}

\begin{abstract}
Several book reviews were published prior to the publication of "Fear. Trump in the White House" on September 11, 2018, with emphasis on "terrifying scenes" (e.g., John F, Kelly reportedly said that Trump is an "idiot"). These reviews, however, did not discuss two major problems in "Fear," namely, the contexts (i.e., environments, locations, settings, etc.) in which dialogues in "Fear" occurred and the probability that Woodward's "sources" were present in such contexts, as well as the probability that such "sources" remembered and then reported verbatim extensive dialogues between two or more individuals in "Fear," because of the limited capacity of the human short-term memory. This commentary suggests that Woodward did not "fabricate" the contents of "Fear," as claimed by some in the White House, but argues that Woodward honestly believed what his "sources" reported to him without questioning such "sources" regarding the two major problems in "Fear."
\end{abstract}

\section{Keywords}

Recall, Dialogues, Fear, Memory, Sources, White House

\section{Introduction}

Before the publication of "Fear: Trump in the White House" (henceforth, "Fear") on September 11, 2018, it was the number one bestseller on Amazon, with over one million copies ordered. The reason for this successful pre-order of "Fear" was that prior book reviews reported "terrifying scenes" (Dwight Garner, New York Times, Sept. 5, 2018) that readers of "Fear" should not make the mistake to miss. According to Woodward, those "terrifying scenes" were reported by "sources" (i.e., informants) he interviewed to write "Fear." Examples of these "terrifying scenes" include Gary Cohen (Trump's top economic advisor in the White House) and Rob Porter (the staff secretary) keeping documents out of 
Trump's desk in the Oval Office to prevent him signing something that Cohn and Porter thought was unwise to sign, such as pulling the United States out of the North American Free Trade Agreement. During a meeting in the Pentagon, Secretary of State Rex Tillerson reportedly said that Trump "is a fucking moron." John F. Kelly, Trump's chief of staff, reportedly said that Trump is "an idiot," adding that "It's pointless to try to convince him of anything. He's gone off the rails. We're in Crazy town. I don't even know why any of us are here. This is the worst job I've ever had." James Mattis (Defense Secretary) reportedly said to close associates that Trump behaves and has the understanding of "a fifth or six grader." Cohn and Porter denied that event, and Kelly, Mattis, and Tillerson said that they did not say those words.

Prior book reviews emphasize these "terrifying scenes" which served as major headlines for the free advertisement of "Fear" in the news media Trump considers "fake news media" and the "enemy of the American people" (e.g., ABC, CBS, CNN, MSNBC, New York Times, and Washington Post). Prior book reviews, however, did not carefully screened "Fear" regarding the probability that thousands of verbal exchanges or extensive dialogues mentioned in the book are most likely examples of fiction mixed with real events. The aim of this commentary is to help readers of "Fear" to find out when they are reading in "Fear" about real events versus events produced by the imagination of Woodward's "sources."

This commentary includes eight sections. Section 1 introduces the main topic, with emphasis on prior book reviews on "Fear." Section 2 suggests that "Fear" is not a "fabricated" story, but a reflection of Woodward's honestly reporting what his "sources" told him verbatim. This section also introduces two major problems in "Fear." The first problem deals with the probability that Woodward's "sources" were present during extensive dialogues or verbal encounters among Woodward's characters in "Fear," given the context (i.e., setting, environment, location) where such dialogues occurred. The second problem deals with the probability that verbatim reports provided to Woodward by his "sources in "Fear" are most likely fictional or invented by such "sources," because of the $1 i$ mited amount of details one is able to store in short-term memory and then later recall and report verbatim. Section 3 deals with the first problem. The second problem is discussed in Section 4. In Section 5, the discussion centers on Woodward's habit to add words to characters in "Fear," meaning citing words, phrases, or dialogues without putting them in quotations to reflect the source for the particular verbal encounter. Another problem with "Fear" is the report of extensive verbal exchanges among people cited in the book but in the absence of the exact date when such exchanges occurred. This situation is briefly discussed in Section 6. A general standard in the editorial process including multiple chapters in a given book is that in each chapter the author is expected to discuss a single topic dealing with the overall message of the book. In "Fear," however, readers are likely to conclude that it is difficult to keep track of unrelated topics or themes discussed in the same chapter. Section 7 is devoted to this scenario. The overall discussion for this commentary is included in Section 8. 
Before I comment on Woodward's "Fear," it is important to alert readers that although this commentary may validate some of the White House's responses to Bob Woodward's book, this is a scholarly critique of "Fear" which reflects editorial standards I have used in prior book reviews I have published in peer-reviewed journals (e.g., Paniagua, 2004, 2006, 2007, 2010).

\section{Fabricated Stories versus Woodward's Believing in His Sources}

On September 4, 2018, White House Press Secretary Sarah Huckabee Sanders said that "Fear" is "nothing more than fabricated stories." This observation did not agree with book reviews prior to the publication of "Fear." For example, Jill Abramson (Washington Post, Sept. 6, 2018) reported that Woodward's book "is based on eyewitness recollections, often supplemented with dates and transcripts of conversations [between Woodward and his sources]." According to David Martin (CBS News, Sept. 4, 2018), "Woodward is very confident of his information, much of which comes from diaries and notes made by participants [i.e., Woodward's 'sources'] in the events." Dwight Garner suggested that stories in "Fear" are not invented by Woodward because he "named sources for scenes" (New York Times, Sept. 5, 2018). Throughout “Fear," however, Woodward did not report either the method he used to validated those "transcripts of conversations" or the method he employed to be sure that "participants" ["sources"] were actually present during the context of those "conversations." Woodward also did not describe the method he used to verify that the "information" provided by his "sources" in "diaries and notes" was valid and/or reliable. In addition, it does not appear that Woodward actually "named sources for scenes." Across the entire book, Woodward reported "sources" but without actually giving the name for any particular "source."

Rather than "fabricated stories," Woodward honestly believed and then reported what his "sources" told him, but he reported the events in a way that sounds more like a novel with many dialogues difficult to validate. The reason for this conclusion is that conversations among people in "Fear" were either impossible to record verbatim given the context (i.e., the environment, place, or setting) in which those conversions occurred, or because of the limited amount of information one can memorize after listening to several people talking and then report such conversations verbatim (i.e., repeating words exactly the way they were uttered by the speaker during a conversation involving two or more individuals). This commentary argues that Woodward did not "fabricate" extensive verbal encounters in "Fear." On the contrary, it appears that Woodward believed what his "sources" told him verbatim without validating the context in which the particular verbal encounter occurred or without questioning the limited capacity of his sources' short-term memory.

It is important to observe that, in the section "Source Notes," Woodward pointed out that information for the prologues and each of the 42 chapters in 
"Fear" "comes primarily from multiple deep back-ground interviews with firsthand sources" (e.g., see p. 363, italics added). In addition, in the section entitled "Note to Readers" Woodward informed that "nearly all [his sources] allowed me to tape-record our interviews so the story could be told with more precision" (p. $\mathrm{xv)}$ ). Woodward, however, did not inform readers that he did not videotape or digitally record hundreds of verbal exchanges or extensive dialogues among individuals he mentioned in "Fear." Therefore, one would assume that all verbal encounters or dialogues in "Fear" are the product of Woodward's "sources" and not the product of individuals reportedly engaged in such verbal encounters or dialogues.

\section{The Context to Validate Verbatim Reports in "Fear"}

The following examples illustrate Woodward's failure to validate the context (i.e., the place or environment) in which dialogues in "Fear" were reported to by his "sources." According to Woodward, during the 2016 campaign Trump said "I want everyone to leave except Kellyanne [Conway]" (p. 17, italics added). Woodward then reported a long dialogue (see pages 17-18) between Trump and Kellyanne. In this context, the problem with "Fear" is that it is difficult to validate that such a long dialogue actually happened because only Trump and Kellyanne were present during the context of that dialogue. Another example is a long conversation between Trump and Senator Lindsey Graham. According to Woodward, Trump was at Mar-a-Lago and "about midnight [italics added], Trump called Senator Lindsay Graham" and asked "Did I wake you up?" Graham replied "Yeah." Trump said "Sorry" and they then engaged in a long conversation covering two pages in "Fear" (see pages 151-152). It is plausible to assume that during that verbal encounter between Trump and Graham at midnight none of Woodward's "sources" were present, for two obvious reasons. First, Trump most likely was alone with his wife (and probably with his son, Barron) when he called Graham "at midnight." Second, the answer from Graham (i.e., "Yeah") suggests that he was sleeping in his bedroom (probably by himself, but for sure without of one of Woodward's "sources"). In this example, Trump probably did call Senator Graham at midnight, but the probability that someone recorded their conversation verbatim is zero, for reasons cited above.

Woodward also reported that "Early one morning in February [no exact date given], a team of senior intelligence officials came to Priebus's West Wing office" (p. 83), among them Andrew McCabe. "After the security briefing and everyone cleared out, McCabe shut the door to Priebus's office" (p. 84, italics added) and both men engaged in an extensive verbal exchange Woodward's "sources" did not have the opportunity to record because only McCabe and Priebus were present during that meeting. Table 1 shows additional examples regarding the context in which verbal encounters occurred in "Fear" and the impossibility to record such encounters verbatim given the context (i.e., setting) where they occurred. For example, in Chapter 1, page 1, the context is a phone call between Bossie and Bannon alone. 
Table 1. Additional examples of the context of conversations in "Fear" impossible to be reported verbatim.

\begin{tabular}{ccccc}
\hline Chapter & Page & Paragraph & Context & Speaker/Listener \\
\hline 1 & 1 & $1^{\text {st }}, 2^{\text {nd }}, 3^{\text {rd }}$ from top & Phone call & Bossie/Bannon \\
20 & 162 & $2^{\text {nd }}$ from top & Alone in OF/W & Bannon/Trump \\
23 & 200 & $2^{\text {nd }}$ from top & Alone PP/W & Quarles/Dowd \\
28 & 226 & $3^{\text {rd }}$ from top & Alone in PO/W & Tillerson/Priebus \\
28 & 234 & $5^{\text {th }}$ from top & Private Cabin AFO & Trump/Priebus \\
29 & 242 & Several paragraphs & White House Residence & Porter/Trump \\
30 & $248-249$ & Several paragraphs & Alone in PDR/W & Cohn/Trump \\
31 & $253-254$ & Several paragraphs & Phone call & Bannon/Kelly \\
31 & 257 & Several paragraphs & Phone call & Sessions/Bannon \\
31 & 259 & $2^{\text {nd }}, 3^{\text {rd }}, 4^{\text {th }}$ from top & Phone call & Trump/Graham \\
32 & 268 & $5^{\text {th }}$ from top & Alone in Kelly's office & Porter/Kelly \\
34 & 281 & Several paragraphs & Private Cabin AFO & Trump/Porter \\
\hline
\end{tabular}

Source: Woodward, B. (2018). Fear. Trump in the White House. New York, NY: Simon \& Schuster. Note. OF = Oval Office/White House; PP = Patriot Plaza/White House; PO = Priebus Office/White House; $\mathrm{AFO}=$ Air Force One; PDR/W = Private Dining Room/White House.

\section{The Limited Capacity of Woodward's Sources' Short-Term Memory}

According to Edger Dale's Cone of Experience applied to short-term human memory, one would remember about $70 \%$ of a conversion if one was actively involved in such conversation. If one only listens to several people engaged in a conversation (i.e., a passive listener), one would remember only $20 \%$ of what people were saying (see figure 1 in Davis \& Summers, 2015). In the case of "sources" used by Woodward to write "Fear," if they were indeed present during verbal exchanges among individuals in "Fear," they were most likely passive listeners. This means that such "sources" probably invented $80 \%$ of what they heard during those verbal exchanges.

In addition, regardless of being an active participant or a passive listener, researchers investigating short-term human memory have found that an individual only can store between 5 and 9 items (e.g., letters, digits, words) in his or her short-term memory during a particular verbal exchange or dialogue. This finding is known as the "magic number 7" (Chen \& Cowan, 2009; McLeod, 2009; Cowan, 2010; Miller, 1956; Schweickert \& Boruff, 1986; Shiffrin \& Nosofsky, 1994), in that the short-term memory of a given individual can only store 7 (plus or minus 2 items). Cowan (2001), however, reviewed the literature on this topic and concluded that the capacity limit for short-term memory is four items, plus or minus one (e.g., letters, words, sentences) and this finding is now known as the "magic 4" (see also Gobet \& Clarkson, 2010). Several of Woodward's "sources," however, reported to him a number of words way above those find- 
ings. For example, on page 241 one of those "sources" reported that Sarah Huckabee Sanders reportedly said 98 words during a verbal exchange with Trump. According to the above findings, that "source" could not actually store 98 words in his or her short-term memory and then repeat verbatim those words to Woodward several months later.

It is also very difficult (almost impossible) to remember verbatim the flow of the conversation word by word, particularly when several individuals are talking with few seconds of interruption among them. Another problem one encounters when memorizing a conversation and then trying to repeat it verbatim is that the longer one waits to report the content of the conversation, the less information one is able to recall and report verbatim (McLeod, 2009; MacLeod \& Nelson, 1984; Peterson \& Peterson, 1959). Many of the dialogues in "Fear" were reported by Woodward's "sources" several months after the particular event occurred. Finally, Gilchrist, Cowan, \& Naveh-Benjamin (2008) found that the ability to recall short-term memory events (e.g., verbal exchanges or complex long dialogues among individuals mentioned in "Fear") decreases with aging (i.e., as we grow older, the probability of remembering short-term events drastically decreases). Woodward, however, did not report the age of his "sources," which would help to consider the findings reported by Gilchrist et al. (2008) in the context of "Fear."

The following examples in "Fear" show that dialogues among individuals mentioned in "Fear" are most likely fictional or invented by Woodward's "sources" because of that limitation the short-term human memory associated with our ability to memorize and then repeat verbatim extensive verbal encounters or dialogues between two or more individuals.

According to Woodward (see Chapter 11, pp. 86-87), General McMaster went to Mar-a-Lago to meet with Trump and Bannon for about two hours. Bannon "offered [to McMaster] his usual advice" (p. 86), in a paragraph with 7 lines and many words Bannon reportedly said. This was followed by a dialogue between Bannon and McMaster, with many words Woodward's "source," for sure, could not recall and then report verbatim to Woodward. That meeting also included another "terrifying scene" reported in prior book reviews with emphasis on "Fear" when Trump, at the end of the meeting, apparently did not know General McMaster and asked Bannon, "Who was that guy?" Trump then added, "He's dressed like a beer salesman." In the same scenario at Mar-a-Lago (see pp. 88-90), Woodward quoted several dialogues in two and half pages involving Trump, General Robert Caslen, General McMaster, Bannon, John Bolton, etc. This is the moment in "Fear" when Trump offered the job to McMaster after a long dialogue between them. Woodward reported those dialogues at Mar-a Lago believing that his "source" was actually able to recall them verbatim, but without taking into consideration that his "source" was probably inventing such dialogues because of the limited capacity of the short-term human memory preventing Woodward's "source" from reporting verbatim all words in such dialogues. 
The only two events clearly factual in this scenario are that those conversions occurred at Mar-a-Lago and that Trump announced on television that General McMaster "will become the national security advisor" (p. 89). Such verbatim reports of dialogues at Mar-a-Lago are most likely fictional, invented by Woodward's "sources."

On page 208, Woodward cited a long dialogue between Cohn and Trump reported by one of his "sources." According to Woodward, this dialogue occurred on February 23, 2018 in the "prep session in the Oval Office" (p. 208). In "Fear" this dialogue between Cohn and Trump covered about one and a half pages with many words practically impossible for that "source" to memorize and then repeat verbatim to Woodward because of the problem of the limited capacity of our short-term memory discussed above. In addition, one would assume that Woodward's "source" did not report that dialogue to Woodward exactly on February 23, but instead, the "source" waited for several weeks or perhaps months to make that report. As noted earlier, research findings suggest that the longer one waits to report verbatim a dialogue between two or more individuals, the ability to make a reliable report about a dialogue substantially diminishes (McLeod, 2009). These research findings clearly apply to Woodward's "source" in the context of the February 23 verbal encounter between Cohen and Trump because Woodward's "source" most likely reported to Woodward that encounter weeks or months after it occurred in February 23.

"Just before 10 a.m. on July 20 ... sixth months into his presidency, Donald Trump crossed the Potomac River to the Pentagon" (p. 219) to meet with his advisers in the Tank. [According to Woodward, "The Tank is the Pentagon's secure meeting room for the Joint Chiefs of Staff," p. 218]. In addition to Trump, this July 20 meeting included retired Marine General James Mattis, Gary Cohn, Steve Bannon, Rex Tillerson, Steve Mnuchin, Reince Priebus, and General Joseph Dunford. These individuals discussed issues ranging from free trade, the war in Afghanistan, the Iran nuclear deal, and troops in South Korea, with extensive dialogues and with Trump actively participating. Woodward used about five pages of "Fear" citing verbatim what each person in that meeting said, as per Woodward's "source." Assuming that one of Woodward's "sources" was also present during that meeting, the probability that this "source" was able to keep track of all words said during multiple dialogues, memorizing specific verbal exchanges among participants, and then able to repeat verbatim to Woodward what such participants were saying during the "Tank" meeting is less than zero. Even if Woodward's "source" took notes during this meeting he or she was not able to keep track of each individual's words because the flow of the conversation was too rapid (according to its format in "Fear" on pages 219-224, and particularly on page 223). Woodward again failed to confront his "source" about the probability someone would be able to remember multiple dialogues, extensive verbal exchanges, and many words involving multiple speakers without the help of either audio or video recording of the event. 
A National Security Council meeting was scheduled by Lieutenant General $\mathrm{H}$. R. McMaster in the Situation Room on January 19, 2018 (see p. 305). Key participants in this meeting included Tillerson, Mattis, retired Marine General Kelly, McMaster, Dunford, Cohn, and Trump. This discussion covered about two pages in "Fear" with specific verbal exchanges very difficult to be remembered verbatim by Woodward's "sources." According to Woodward, when "the president left" (p. 307) that meeting on January 19, his "source" reported that "among the principals there was exasperation [with the following questions]" (p. 307): "Why are we having to do this constantly?" "When he [Trump] is going to learn?" (pp. 307-308). This was the moment when "Mattis was particularly exasperated and alarmed, telling close associates" (p. 308) that Trump's actions and understanding resemble those of "a fifth or sixth grader" (p. 308). As noted above, General (retired) Mattis denied he said these words against Trump's cognitive abilities. It is important to observe that Mattis' confession of telling the truth has not yet been contradicted by Woodward with additional evidences from outside his "sources” (e.g., consulting with Mattis' “associates” to validate reports from Woodward's "source" in this specific situation).

Dowd and Trump met in "the White House residence on Saturday, January 27, 2017, around 1 p.m." (p. 328). During this meeting, Dowd and Trump engaged in a long conversation in which Dowd wanted to know how Trump would answer specific questions potentially associated with the Muller's investigation. In preparation for this "practice session" ("Fears," p. 328), Dowd said "If the questions seem harmless, don't treat them that way ... And I'll give you the standard advice ... just answer the questions. Okay? Got it?" (pp. 328-329). Trump answer "Yes," followed by three pages of questions from Dowd and answers to each question by Trump. During this meeting on January 27, Dowd asked 15 questions (see pp. 329-331), and he felt Trump didn't answer such questions in way to convince Muller that Trump was telling the truth, prompting Dowd to say "Mr. President, that's why you can't testify" (p. 332). The ability for Woodward's "sources" to remember verbatim all 15 questions from Dowd, as well as Trump's answers to each question is beyond the limited amount of information one can store in our short-term memory. This observation is particularly true in the case of remembering verbatim two long paragraphs with many words Dowd reportedly said on page 332. The first paragraph starts with the sentence "Mr. President, that's why you can't testify" and it includes 74 words. The second starts with "No ... Why don't we exhaust this thing?" with 87 words, totaling 161 words between both paragraphs. Actually, Dowd himself would testify that he could not remember he said all these words exactly the way Woodward's "source" reported them verbatim to Woodward.

Perhaps the best example regarding the limited capacity of Woodward's "sources" short-term memory is "a meeting ... arranged for 2 p.m. on Monday, March 5, at Muller's office" (p. 343), in which "Muller was accompanied by Quarles and three other prosecutors" (p. 343) and "Dowd came with [Jay] Sekulow and another lawyer" ( $\mathrm{p}$ 142). It appears that during the entire meeting Dowd 
did much of the talking with Muller interjecting on some occasions. Dowd said to Muller, "Where are the questions." Muller replied, "I don't know ... Seems to me you're not going to testify." Dowd said, "Under the circumstances, exactly right." Muller then said, "Well, you know ... I could always get a grand jury subpoena" (p. 343). Dowd replied, "You go right the fuck ahead and get it" (p. 344). According to Woodward's "source," Dowd's aggressive verbal response was followed by 445 words Dowd reportedly said in seven paragraphs in "Fear" (see pp. 344-345). Again, the probability that someone would be able to store 445 words in his or her short-term memory "on Monday, March 5" (p. 343) and then repeat them verbatim to Woodward about five months prior to the release of "Fear" on September 11, 2018 is less than zero.

Several paragraphs in "Fear" are too long for someone to remember and then repeat verbatim. For example, one of Woodward's "sources" told him that "On March 7, Trump invited Graham to lunch at the White House" (p. 100) and that Graham reportedly said to Trump the following 151 word in a single paragraph on page 101: "Before we go into lunch ... I want to apologize to you for a very fucked-up Republican majority. Congress is going to fuck up your presidency. We have no idea what we are doing. We have no plan for health care. We re on different planets when it comes to cutting taxes. And you re the biggest loser in this ... Now you' re the one who can do it. You' re a deal make. These leaders in congress don't know how to do something as simple as buying a house. If there was eve time for a deal maker, this is it. There are a lot of good people, but most of them never made a deal in private sector. There are not five people on Capitol Hill Id let buy me a car. Id let you buy me a car. And there's what I want to convince you of: that you'd let me buy your car" (italics added).

The above example is cited in Table 2, which shows additional examples of paragraphs with too many words in "Fear" impossible to be remembered by Woodward's "sources." For example, in Chapter 42, pages 344-345, Dowd reportedly said to Muller 115 words. Using Table 2, go ahead and say to your best friend all those words uttered by Graham to Trump, Bannon to Trump, Porter to Trump, Trump to Porter, Sanders to Trump, Sessions to Bannon, Cohn to Porter, Dowd to Trump, and Dowd to Muller in "Fear," and then ask him or her to repeat those words verbatim to you in the form of dialogues among those individuals. The probability your friend will repeat all the words verbatim and cross specific dialogues is, again, less than zero; and this is why Woodward's "sources" probably invented those words and dialogues in Table 2.

\section{Woodward's Habit to Add Words to His Characters in "Fear"}

On many occasions, it appears that Woodward has the habit of putting words in the mouths of his characters that are not reported verbatim by his "sources" (i.e., citations of words without quoting the person who spoke such words). For example, during "dinner in the Blue Room, Trump pulled out a letter ... [and] read 
Table 2. Examples of reports with too many words in "fear" impossible to be remembered by woodward's sources.

\begin{tabular}{cccccc}
\hline Chapter & Page & Paragraph & Speaker & Speaker's Words & Listener \\
\hline 12 & 101 & $3^{\text {rd }}$ from bottom & Graham & 151 & Trump \\
20 & 162 & $2^{\text {nd }}$ from top & Bannon & 77 & Trump \\
26 & 216 & $2^{\text {nd }}$ from bottom & Porter & 53 & Trump \\
26 & 216 & $1^{\text {st }}$ from bottom & Trump & 66 & Porter \\
29 & 241 & $4^{\text {th }}$ from top & Huckabee Sanders & 98 & Trump \\
31 & 257 & $6^{\text {th }}$ from bottom & Sessions & 55 & Bannon \\
33 & 271 & $2^{\text {nd }}$ from bottom & Cohn & 98 & Porter \\
40 & 332 & $2^{\text {nd }}$ from top & Dowd & 74 & Trump \\
40 & 332 & $2^{\text {nd }}$ from bottom & Dowd & 83 & Trump \\
42 & 344 & $2^{\text {nd }}$ from top & Dowd & 83 & Muller \\
42 & 344 & $3^{\text {rd }}$ from top & Dowd & 100 & Muller \\
42 & $344-345$ & $5^{\text {th }}$ from top & Dowd & 115 & Muller \\
\hline
\end{tabular}

Source: Woodward, B. (2018). Fear. Trump in the White House. New York, NY: Simon \& Schuster.

it to Cindy McCain" (p. 104) with the following words Trump did not say but Woodward: I would very much like you to be my ambassador at large for trafficking (pp. 104-105, italics added to indicate words are not direct quotations from the speaker, same observation in following examples). Woodward also put the following words in Trumps' mouth: The major missile defense system might cost $\$ 10$ billion over 10 years, and it wasn't even physically in the United States (p. 106, italics added). In "Fear," these words are not in quotation.

During "a principal Committee meeting" (p. 119), Woodward put the following words in the mouth of Sessions: You' re basically walking the president into exactly what he doesn't believe in, to a place he doesn't want to go ... We' re losing too many lives in Afghanistan. I don't understand what you guys don't get. This is not where the president's at" ( $p$. 120). During the same meeting, Priebus did not say the following words but Woodward: "You [apparently Sessions and others in that meeting] have not spent the time working with the president on what his basic philosophy and foreign policy positions are, and why (p. 120, italics added).

According to Woodward, "the National Security Council gathered in the situation Room at 10:00 ... July 19, to brief Trump on the Afghanistan and Pakistan strategy" (p. 124). Trump is quoted to say to Mattis, Dunford and McMaster "I don't care about you guys" (p. 124) and Woodward then put in the mouth of Trump the following words without quoting him: We are losing big in Afghanistan. It's a disaster. Our allies aren't helping ... NATO is a disaster and a waste ... Pakistan isn't helping us. They're not really a friend ... The Afghan leaders were corrupt and making money off the United States... The soldiers on the ground could run things better than you [i.e., the generals]. They could do a 
much better job. I don't know what the hell we're doing (pp. 124-125, italics added).

The following narrative includes three additional examples among many in "Fear." First, Priebus and Tillerson met at "5:15 p.m. on Tuesday, July 18" (p. 211). During this meeting (see p. 211), Woodward included the following words Priebus did not say (again, because they are not in quotation): Tell me ... how things are going? Are you on track to achieve your primary objectives? How is the relationship between the State Department and the White House? Between you and the president? The second example is on page 255. According to Woodward, during a "under the plan for the NSC meeting on August 18" (p. 255) Woodward observed that "Sessions began by noting that he had been on the Senate Armed Services Committee since 9/11" (p. 255). Woodward then reported that Sessions said the following 74 words he actually did not uttered but Woodward: $P$ ve always heard the same thing. We re six months to 18 months from turning Afghanistan around. Time and time again, the same. You guys have always been wrong. Look at the major decisions to add tens of thousands of troops by Obama, he hammered. A major turnaround promised and expected. Always wrong. That's why we've been here for 16 years. The Taliban now control more than half the country. Withdraw now. Give it up (p. 255, italics added). The third example is the last five words in "Fear" (see p. 357). According to Woodward, Dowd felt that "Trump had one overriding problem that Dowd knew could not bring himself to say to the president: 'You' re a fucking liar'" (p. 357, italics added). Dowd did not say these five words, Woodward said them.

\section{When Verbal Exchanges or Dialogues Occurred?}

On many occasions, Woodward reported verbal exchanges or dialogues among his characters in "Fear" but without including the exact date when the particular conversation occurred. In the section of "Fear" entitled "Author's Personal Note," Woodward wrote that his assistant, Evelyn M. Duffy, "made sure we built the story around specific scenes with specific dates" (p. xi, italics added). Woodward's assistant, however, missed many "specific dates" across many verbal exchanges or dialogues in "Fear." Without citing the exact date when two or more individuals were talking in "Fear," such individuals would have the "green light" to either deny that they were present during the particular conversation or uttered words reported by Woodward's "sources." For example, on page 286 Woodward reported that "in a small group meeting in his office one day" (italics added), Kelly said of the president, "He's an idiot" [see Introduction for more words Kelly reportedly said on that "one day"]. As observed above, Kelly denied he said those words: "The idea I ever called the President an idiot is not true" (Jackson, 2018, italics added). Below are additional examples illustrating this situation in "Fear."

Trump reportedly said lot of words "during a spring meeting in the Oval Office” (p. 105, italics added). Page 106 includes Trump's words during that meet- 
ing, which he would be able to deny because Woodward did not provide the exact date for the meeting. In this example, Trump would not deny he had many, many meetings during "spring" time in the Oval Office. In the absence of the exact date when Trump apparently said those words, Trump would argue that he did not say those words quoted by Woodward on page 106.

"Years ago at a Marine Corps parade, Dowd had run into Muller when he was FBI director" ("Fear," p. 170, italics added). Muller asked Dowd, "What are you up to?" Dowd replied, "I'm representing Congressman Don Young." Muller said, "That crook?" and added "How could you do that?" Dowd answered, "That's our system" (p. 170). Without the exact date for this conversation that happened "years ago," both Dowd and Muller would argue they did not engage in such conversation, particularly Muller saying to Dowd that Don Young is a "crook."

\section{Discussion of Multiple Themes in Same Chapter}

As observed previously, when the book includes multiple chapters the author is expected to discuss a single theme or topic in each chapter dealing with the general message of the book. Discussing unrelated or unconnected topics in the same chapter is no expected. Across most chapters in "Fear," however, readers would have difficulty keeping track of unconnected themes in the same chapter. For example, in Chapter 32 Woodward discussed the absence of "a process for making and coordinating decisions" [in the White House]" (p. 261); later the theme is about "Rear Admiral Ronny Jackson, the president's White House physician" discussing with Kelly about Trump under "lots of stress recently" and what to do "to deal things back, or to ease up on his [Trump] schedule" (p. 266). This theme is then followed by a completely different series of themes dealing with "steel tariffs" and "tax reform" (pp. 266-267) and "immigration" (p. 267), ending with Trump complaining about not having "any good lawyer ... I have terrible lawyers" (p. 268) and Porter and Kelly worrying that Trump is "so consumed and distracted" (p. 268) by the Muller's investigation that it could be a major "challenge [for Trump] to continue to do the work and making decisions-effectively to the president" (p. 268).

Another example is Chapter 39, which begins with Trump and Graham playing golf "at the Trump International Golf Club in West Palm Beach" (p. 317) where Graham praised Trump for his accomplishments. After a brief verbal exchange between Trump and Graham, "Fear" quickly moves to the next topic unrelated to the first, namely, a discussion on "immigration plan for the dreamers" (a theme also known as DACA = Deferred Action for Childhood Arrivals, p 317). The DACA theme is then followed by a new unrelated theme, namely, Trump wanting to know more about "the libel law" (p. 118). This "libel law" discussion is then followed by a return to DACA and other unrelated topics (e.g., Trump's disagreement regarding "having all those people from shithole countries come here," p. 320, including Haiti and African countries, and Trump's 
preference from having people coming from Norway and Asian countries). Readers of "Fear" will encounter additional examples across chapters where they would need to pay close attention when Woodward moves from one theme to another unrelated theme without alerting the reader that this move will occur.

\section{Discussion}

I agree with John Bacon (USA Today, Sept. 4, 2018) that "Woodward cited as his sources hundreds of hours of interviews with mostly unnamed Trump aides and others." Woodward, however, did not consider two important factors before he agreed to include short or extensive dialogues reported verbatim to him by his "sources," namely, the context in which those dialogues occurred and the limited amount of details one is able to memorize and then report verbatim after listening to two or more individuals talking about a particular event, especially if one is a passive listener. Attention to these factors would result in a book that is factual with minimal fictional details. In its present format, however, "Fear" is a book of fiction mixed with real events. As noted earlier, I disagree with the argument from the White House in that Woodward "fabricated" all dialogues among individuals mentioned in "Fear." On the contrary, Woodward honestly believed what his "sources" told him but without carefully considering the aforementioned factors to validate the words, extensive verbal exchanges or dialogues his "sources" reported verbatim.

Prior book reviews emphasize what I consider dramatic observations in "Fear," with the goal to get the attention of readers. As noted earlier, when readers are told in such book reviews that they will read about "terrifying scenes" this situation, for sure, would prompt or encourage readers to buy and read "Fear." The same point applies when readers are told that "fear depicts a White House awash in dysfunction" (Lloyd Green, Sept. 8, 2018, The Guardian), or that in "Fear" readers find "plenty to discover in this meticulously reported account of the infighting, dysfunction and impulsive decision-making in President Trump's administration" (John Diaz, Sept. 18, 2018, The Chronicle's editorial, italics added). The present commentary, instead, alerts readers about the probability that Woodward's "sources" were, indeed, present in a given context (i.e., setting) during extensive verbal encounters among individuals mentioned in "Fear" (see Section 3), as well as the impossibility for someone to recall and then report verbatim to Woodward paragraphs with hundreds of words reportedly said by such individuals in the Trump administration (see Table 2) because of the limited capacity of the human short-term memory (see Section 4).

It is important to observe that Woodward is among the most celebrated journalists of our time because, as noted by Lloyd Green (Sept. 8, 2018), with Charles Bernstein who is also among the top journalists in the world, Woodward "did so much to bring down Richard Nixon"

(https://www.theguardian.com/us-news/2018/sep/08/fear-review-bob-woodwar d-donald-trump). In the case of "Fear," however, it appears that Woodward 
agreed with his "sources" without carefully validating their reports with emphasis on the discussion in Sections 3 and 4 in this commentary.

\section{Author Biography}

Freddy A. Paniagua received his Ph.D. from the University of Kansas, and his postdoctoral degree from Johns Hopkins University School of Medicine. He is a retired, tenured professor from the Department of Psychiatry and Behavioral Sciences and currently adjunct professor, University of Texas Medical Branch (UTMB) at Galveston, USA. He is Fellow with Life Status membership in the American Psychological Association (APA). He has authored over 50 articles in peer-reviewed journal (including book reviews), six scholarly books, and two fiction books.

\section{Fear: Trump in the White House}

\section{By Bob Woodward}

Simon \& Schuster, 2018. 421 pp. Hardcover-ISBN978-1-50011-7551-0. \$30.00. eBOOK-ISBN9781501175534. \$12.99

\section{Acknowledgements}

I am grateful to Dr. Sandra A. Black for her insightful and constructive suggestions. Dr. Black's suggestions significantly improved the content of this manuscript.

\section{Conflicts of Interest}

The author declares no conflicts of interest regarding the publication of this paper.

\section{References}

Chen, Z., \& Cowan, N. (2009). Core Verbal Working Memory Capacity: The Limit in Words Retained without Covert Articulation. Quarterly Journal of Experimental Psychology, 62, 1420-1429. https://doi.org/10.1080/17470210802453977

Cowan, N. (2001). The Magical Number 4 in Short-Term Memory: A Reconsideration of Mental Storage Capacity. Behavioral and Brain Sciences, 24, 87-114. https://doi.org/10.1017/S0140525X01003922

Cowan, N. (2010). The Magical Mystery Four: How Is Working Memory Capacity Limited, and Why? Current Directions in Psychological Science, 19, 51-57. https://doi.org/10.1177/0963721409359277

Davis, B., \& Summers, M. (2015). Applying Dale's Cone of Experience to increase Learning and Retention: A Study of Student Learning in a Foundational Leadership Course. In Proceedings (Engineering Leaders Conference 2014). http://dx.doi.org/10.5339/qproc.2015.elc2014.6

Gilchrist, A. L., Cowan, N., \& Naveh-Benjamin, M. (2008). Working Memory Capacity for Spoken Sentences Decreases with Adult Aging: Recall of Fewer, But Not Smaller Chunks in Older Adults. Memory, 16, 773-787.

https://doi.org/10.1080/09658210802261124 
Gobet, F., \& Clarkson, G. (2010). Chunks in Memory: Evidence for the Magical Number Four ... or Is It Two? Memory, 12, 732-747.

https://doi.org/10.1080/09658210344000530

Jackson, D. (2018). Trump Calls Woodward's Book 'A Con on the Public'; Kelly Denies Calling President an 'Idiot.' USA Today.

https://www.usatoday.com/story/news/politics/2018/09/04/john-kelly-says-he-did-notcall-donald-trump-idiot/1191721002/

MacLeod, C. M., \& Nelson, T. O. (1984). Response Latency as Response Accuracy as Measures of Memory. Acta Psychologica, 57, 215-235.

https://doi.org/10.1016/0001-6918(84)90032-5

McLeod, S. A. (2009). Short Term Memory.

https://www.simplypsychology.org/short-term-memory.html

Miller, G. (1956). The Magical Number Seven, Plus or Minus Two: Some Limits on Our Capacity for Processing Information. The Psychological Review, 63, 81-97. https://doi.org/10.1037/h0043158

Paniagua, F. A. (2004). Culturally Sensitive Mental Health Services for Latinos or Hispanic Families. [Review of Counseling Latinos and La Familia: A Practical Guide by A. L. Santiago-Rivera, P. Arredondon, \& M. Gallardo-Cooper]. Contemporary Psychology, 49, 54-57. https://doi.org/10.1037/004245

Paniagua, F. A. (2006). From the Terrorists' Point of View. [Review of From the Terrorists' Point of View: What They Experience and Why They Come to Destroy by Fathali M. Moghaddam]. Journal of Homeland Security and Emergency Management, 3, Article 10. http://works.bepress.com/freddy_paniagua/1/

Paniagua, F. A. (2007, August 15). Understanding Second-Variant Jihadists. [Review of Knowing the Enemy: Jihadist Ideology and the War on Terror by Mary R. Habeck]. PsycCritiques, 52, Article 149.

Paniagua, F. A. (2010). Review of Suicide among Racial Ethnic Minority Groups. Cultural Diversity and Ethnic Minority Psychology, 16, 297-298. https://doi.org/10.1037/a0013374

Peterson, L. R., \& Peterson, M. J. (1959). Short-Term Retention of Individual Verbal Items. Journal of Experimental Psychology, 58, 193-198. https://doi.org/10.1037/h0049234

Schweickert, R., \& Boruff, B. (1986). Short-Term Memory Capacity: Magic Number or Magic Spell? Journal of Experimental Psychology: Learning, Memory, and Cognition, 12, 419-425. https://doi.org/10.1037/0278-7393.12.3.419

Shiffrin, R. M., \& Nosofsky, R. M. (1994). Seven Plus or Minus Two: A Commentary on Capacity Limitations. Psychological Review, 101, 357-361.

https://doi.org/10.1037/0033-295X.101.2.357 